University of Nebraska - Lincoln

DigitalCommons@University of Nebraska - Lincoln

Publications from USDA-ARS / UNL Faculty

U.S. Department of Agriculture: Agricultural

Research Service, Lincoln, Nebraska

2011

\title{
The Use of Cover Crops to Manage Soil
}

T. C. Kaspar

USDA-ARS, tom.kaspar@ars.usda.gov

J. W. Singer

USDA-ARS, jeremy.singer@ars.usda.gov

Follow this and additional works at: https://digitalcommons.unl.edu/usdaarsfacpub

Kaspar, T. C. and Singer, J. W., "The Use of Cover Crops to Manage Soil" (2011). Publications from USDAARS / UNL Faculty. 1382.

https://digitalcommons.unl.edu/usdaarsfacpub/1382

This Article is brought to you for free and open access by the U.S. Department of Agriculture: Agricultural Research Service, Lincoln, Nebraska at DigitalCommons@University of Nebraska - Lincoln. It has been accepted for inclusion in Publications from USDA-ARS / UNL Faculty by an authorized administrator of DigitalCommons@University of Nebraska - Lincoln. 


\title{
The Use of Cover Crops to Manage Soil
}

\author{
T.C. Kaspar and J.W. Singer
}

C over crops are used to manage soils for many different reasons and are known by many different names. Cover crops are literally "crops that cover the soil" and one of their first uses was to reduce soil erosion during fallow periods in annual cropping systems. Cover crops are also known as "green manures," "catch crops," or "living mulch." Green manure cover crops are usually legumes that fix $\mathrm{N}$ and are grown to provide $\mathrm{N}$ to the following cash crop. Catch crops are cover crops that are grown during fallow periods in cropping systems to take up nutrients, especially $\mathrm{N}$, that would be lost if plants are not present. Lastly, living mulches are cover crops that are grown both during and after the cash crop growing season and are suppressed or managed to reduce their competition with the cash crop when it is growing. After the cash crop has matured and before it begins growing again, the living mulch is allowed to grow unhindered. One way to manage living mulches is to restrict them to the "fallow" spaces between crop rows. Orchards or vineyards are sometimes managed with living mulches, but it is also possible to incorporate living mulches into annual cropping systems. Thus, as can be seen from their many names and descriptions, cover crops can fulfill many soil management functions.

In terms of soil management, the basic premise for using cover crops is to reduce fallow periods and spaces in cropping systems. Natural ecosystems typically have some plants growing, covering the soil, transpiring water, taking up nutrients, fixing carbon, and supporting soil fauna for most of the time that the ground is not frozen. Agricultural cropping systems producing grain, oilseed, and fiber crops in temperate regions typically only have living plants for four to six months of the year and are fallow for the remaining six to eight months. Current planting and tilling practices often leave soil bare and exposed during fall, winter, and early spring. Some perennial cropping systems for nut or fruit crops (e.g., almonds and grapes) keep the spaces between rows fallow and tilled for extended periods. As a result of these fallow periods and fallow spaces in annual and perennial cropping systems, soil is left unprotected from erosive forces, nutrients and organic matter are lost or not replenished, runoff increases, soil fauna are stressed, and soil productivity diminishes. Thus, inserting cover crops into fallow periods or fallow spaces in cropping systems can accomplish multiple soil management goals. This discussion is not intended to be a comprehensive review and will focus on the general principles and evidence for using cover crops to manage soil erosion, runoff, soil nutrients, soil physical properties, soil water, soil organic carbon, soil chemical properties, and soil biology.

T.C. Kaspar (Tom.Kaspar@ars.usda.gov) and J.W. Singer (jeremy.singer@ars.usda.gov), USDA-ARS, National Laboratory for Agriculture and the Environment, 2110 University Boulevard, Ames, IA 50011.

doi:10.2136/2011.soilmanagement.c21

Copyright $\odot$ 2011. American Society of Agronomy and Soil Science Society of America, 5585 Guilford Road, Madison, WI 53711, USA. Soil Management: Building a Stable Base for Agriculture. Jerry L. Hatfield and Thomas J. Sauer (ed.) 


\section{Erosion and Runoff}

Reducing water erosion is one of the main reasons for growing cover crops (Langdale et al., 1991). Soils are generally more susceptible to erosion when they are not covered with the canopies of living plants or their plant residues. Annual crop plants, such as corn (Zea mays L.) and soybean [Glycine $\max ($ L.) Merr.], only provide significant canopy cover for four months or less each year. Additionally, crops such as soybean, cotton (Gossypium hirsutum L.), or corn harvested for silage often do not leave enough residues to fully protect the soil between harvest and development of the next crop canopy. Cover crops and their residues reduce erosion through the same mechanisms as the cash crops. However, when cover crops are grown in the fallow intervals between cash crops they extend the time the soil is covered with living plants and also supplement and anchor residues left by annual crops.

The impact of cover crops on erosion processes depends on how much they reduce the forces of soil detachment and transport. Cover crops reduce interrill erosion primarily because they increase the amount and duration of soil cover either with living plants or plant residues. Soil cover is the principal characteristic of cropping systems that affects the amount of interrill erosion. Because interrill erosion results from the detachment of soil particles by raindrop impact, living or dead plant material that intercepts raindrops and dissipates impact energy will reduce interrill erosion. Ram et al. (1960) observed that soil detachment from raindrop impact was reduced as cover crop canopy increased either because of plant density or plant growth. Later, Laflen et al. (1985) showed that the relationship between surface cover and erosion reduction is exponential with smaller decreases in erosion as surface cover approaches 100\%. This explains why the relative benefit of incorporating cover crops into a cropping system depends to some extent on the quantity, duration, and distribution of residues and plant canopies that are normally present in the cropping system throughout the year (Mutchler and McDowell, 1990). For example, Mutchler and McDowell (1990) found that the reduction of erosion by a hairy vetch (Vicia villosa Roth)-wheat (Triticum aestivum L.) winter cover crop mixture was much greater in tilled systems than in no-till systems and much greater in no-till following a soybean crop than following a soybean-wheat double crop. Kaspar et al. (2001), however, showed that oat (Avena sativa L.) or rye (Secale cereale L.) cover crops in no-till soybean reduced interrill erosion in two of three rainfall simulator trials even though residue cover did not increase significantly with cover crops and was already greater than $75 \%$ without cover crops. They hypothesized that the decreases in interrill erosion with cover crops was caused by reduced interrill transport of sediments. They observed that the anchoring of cover crop plants or residues to the soil by roots resulted in the formation of microdams, which probably resulted in sediment deposition. Lattanzi et al. (1974) also observed that increasing amounts of surface residues reduced interrill erosion by intercepting splash transport of sediment, slowing interrill flow velocity, and increasing water film depth behind residue microdams.

Whereas interrill erosion is largely dependent on raindrop impact to detach soil particles, rill erosion relies on the shear force of water flowing in concentrated flow paths to both detach and transport soil particles (Flanagan, 2002). Cover crops can reduce rill erosion by reducing the shear force of flowing water or by increasing the resistance of soil particles to detachment. One way cover crops reduce the shear force of runoff water is by reducing its volume through increased infiltration. This occurs because cover crops prevent surface sealing, increase storage capacity, and improve soil structure (Dabney, 1998). Additionally, cover crops or surface residues (Brown and Norton, 1994) can slow flow velocity at the surface by increasing hydraulic resistance. Lastly, because cover crop plants or residues are anchored to the surface by roots and because they hold other unanchored surface residues in place (Kaspar et al., 2001), flowing water cannot easily move residues and expose the soil surface to shear forces of water (Foster et al., 1982).

Cover crops also reduce both rill and interrill erosion by increasing soil resistance to detachment. Cover crops are known to increase soil organic matter near the soil surface (Wander et al., 1994), which in turn should result in larger, more stable aggregates that are less susceptible 
to detachment (Dabney, 1998). Additionally, cover crop roots can physically bind aggregates together, which makes them even more resistant to detachment by flowing water or raindrop impact. Mamo and Bubenzer (2001) confirmed that plant roots substantially reduced soil detachment and rill erodibility.

A number of field studies have measured significant erosion reductions with cover crops. In Missouri, Zhu et al. (1989) compared soil erosion of no-till soybean with winter cover crops with erosion of no-till soybean without cover crops under natural rainfall. Annual soil loss was decreased $87 \%$, $95 \%$, and $96 \%$ by chickweed (Stellaria media L.), Canada bluegrass (Poa compressa L.), and downy brome (Bromus tectorum L.) winter cover crops, respectively, compared with no cover crops. Apparently, the no-till soybean crop at this location did not produce enough residues to adequately protect the soil. In another Missouri study (Wendt and Burwell, 1985), a winter rye or winter wheat cover crop reduced the annual soil loss of no-till corn grown for silage from $22 \mathrm{Mg} \mathrm{ha}^{-1}$ to $0.9 \mathrm{Mg} \mathrm{ha}^{-1}$ and annual runoff from 245 to $122 \mathrm{~mm}$. In this same study, however, notill corn without silage removal had less soil erosion than no-till corn with silage removal and a cover crop, but both of these treatments had less erosion than corn grown with either moldboard plowing or field cultivating. In Mississippi, Mutchler and McDowell (1990) found that a wheat or hairy vetch cover crop following cotton reduced annual soil loss of conventional-tilled cotton from $74.2 \mathrm{Mg} \mathrm{ha}^{-1}$ to $20.4 \mathrm{Mg} \mathrm{ha}^{-1}$ and that of no-till cotton from $19.2 \mathrm{Mg} \mathrm{ha}^{-1}$ to $2.3 \mathrm{Mg}$ $\mathrm{ha}^{-1}$ when cotton followed soybean. Lastly, a 3-yr rainfall simulator study in Iowa (Kaspar et al., 2001) showed that winter rye cover crops overseeded into no-till soybean in late summer reduced interrill erosion the following spring by $54 \%$ and rill erosion by
90\% compared with no-till without cover crops. Oat cover crops, which winter-kill in Iowa, reduced interrill and rill erosion by $26 \%$ and $65 \%$, respectively. Neither rye nor oat cover crops significantly increased surface cover, which was already greater than $75 \%$ for the no-till soybean without cover crops. Because of the high residue cover, the quantity of interrill erosion was relatively low even for no-till without cover crops. Additionally, the rye cover crop increased infiltration in only 1 of the $3 \mathrm{yr}$. In spite of this, there were substantial reductions in rill erosion. Kaspar et al. (2001) observed that the cover crops prevented soybean residues from moving or dislodging with surface water flow. As a result, the soil surface was not exposed to the shear force of flowing water and this was partly responsible for the cover crops' success in reducing rill erosion.

\section{Phosphorus Losses in Runoff}

Losses of $\mathrm{P}$ from agricultural systems to surface waters are largely dependent on the amount of surface runoff and sediment transport that occurs. Phosphorus is transported in runoff as soluble $\mathrm{P}$ and particulate P (Sharpley and Smith, 1991). Particulate P consists of $\mathrm{P}$ bound to soil sediment and $\mathrm{P}$ contained in organic matter. Sharpley and Smith (1991) summarized research on the effect of cover crops on P losses and found that reductions in total $\mathrm{P}$ losses, which consist mostly of particulate $\mathrm{P}$, ranged from $54 \%$ to $94 \%$ (Table 21/1). This is not surprising considering that cover crops reduce runoff and sediment detachment and transport. They also pointed out, however, that the effects of cover crops on soluble P in runoff were more variable (Table 21/1). Including cover crops in a cropping system sometimes resulted in higher concentrations of soluble $\mathrm{P}$ in runoff

Table 21|1. Literature summary of percent reduction (-) or increase $(+)$ in total $P$, soluble $P$ concentration, or soluble $\mathrm{P}$ in runoff due to winter cover crops (adapted from Sharpley and Smith, 1991).

\begin{tabular}{|c|c|c|c|c|c|}
\hline Reference & Location & Cover crop & $\begin{array}{l}\text { Change in total P } \\
\text { losses in runoff }\end{array}$ & $\begin{array}{l}\text { Change in soluble } \\
\mathrm{P} \text { concentration } \\
\text { in runoff }\end{array}$ & $\begin{array}{l}\text { Change in soluble } \\
\mathrm{P} \text { in runoff }\end{array}$ \\
\hline Angle et al. (1984) & Maryland & Barley & $-92 \%$ & $+460 \%$ & $-13 \%$ \\
\hline Langdale et al. (1985) & Georgia & Rye & $-66 \%$ & $+54 \%$ & $+8 \%$ \\
\hline Pesant et al. (1987) & Quebec & Alfalfa/timothy & $-94 \%$ & $-60 \%$ & $-12 \%$ \\
\hline Yoo et al. (1988) & Alabama & Wheat & $-54 \%$ & $0 \%$ & $-50 \%$ \\
\hline
\end{tabular}


and did not always reduce the cumulative amount of soluble $\mathrm{P}$ in runoff compared with no cover crops. Several studies have shown that soluble $\mathrm{P}$ can be lost in runoff flowing over plant residues (Timmons et al., 1970; Bechmann et al., 2005). However, on an annual basis, plant water use and infiltration would be expected to increase with cover crops, which should reduce the volume of runoff. This would offset to some extent the higher soluble P concentrations of runoff in the presence of cover crops.

\section{Soil Physical Properties}

Soil structure in simple terms is the physical relationship between the solid, liquid, and gaseous phases of soil. The arrangement of soil particles into peds or aggregates determines the size and shape of soil voids or pores and this greatly influences the movement of water and gases in soil. As a result, soil structure can have a substantial impact on plant growth. Conversely, cover crops, like any plants, can alter soil physical and structural properties directly through formation of pores and aggregates by roots or indirectly through the input and decomposition of shoot and root residues. Obviously, a cover crop's impact on soil structure will vary depending on climate, soil type, soil texture, soil depth, tillage, cropping system, cover crop biomass, cover crop species, and cover crop frequency in the crop rotation. For example, Ball-Coelho et al. (2000) reported that in a 3-yr corn-soybean-winter wheat rotation, cover crops after winter wheat and corn had a small effect on stability of microaggregates and no effect on dry-aggregate size distribution or wet-aggregate stability of macroaggregates in the upper 0.075 $\mathrm{m}$ of a sandy soil with conventional, chisel, and no-till tillage systems. They concluded that because microaggregates were more stable than macroaggregates with cover cropping, the binding mechanisms probably involved humic materials or microbial products, which likely were not as important for macroaggregate stability (Degens et al., 1996). Alternately, Dapaah and Vyn (1998) reported an increase in wet aggregate stability in the upper $0.07 \mathrm{~m}$ of a sandy loam and loam soils after only one cycle of annual ryegrass (Lolium multiflorum Lam.), red clover (Trifolium pratense L.), and oilseed radish
(Raphanus satious L.) cover crops. Annual ryegrass maintained greater wet aggregate stability than the other cover crops at samplings from May through September presumably because of more persistent aggregate binding that led to less aggregate breakdown (Dapaah and Vyn, 1998). Tisdall and Oades (1979) reported that perennial ryegrass (Lolium perenne L.) was more efficient than white clover (Trifolium repens L.) in stabilizing aggregates in a loam soil because perennial ryegrass supported a larger population of vesicular-arbuscular mycorrhizal hyphae and had greater hyphal and root length. Results from their electron micrographs revealed hyphae covered with an amorphous material, which they conjectured was a polysaccharide capable of binding clay particles. These studies demonstrate that cover crop impacts on soil aggregation vary with cover crop species, quantity of roots, soil type, and cropping systems.

Patrick et al. (1957) reported that after 25 yr of continuous cotton with tillage on a loam soil, $21.3 \%$ of the aggregates had diameters $>0.21 \mathrm{~mm}$ when a hairy vetch cover crop was included in the cropping system compared with the $11.8 \%$ for a common vetch (Vicia sativa L.) cover crop treatment and $9.5 \%$ for a control without a cover crop. The authors concluded that hairy vetch improved aggregation better than common vetch because hairy vetch produced more biomass than common vetch. The hairy vetch treatment also had a lower bulk density, greater porosity, and greater water holding capacity than the no cover control in the surface $0.06 \mathrm{~m}$ of soil. Benoit et al. (1962) reported greater aggregation and hydraulic conductivity at the surface of a sandy loam soil after 3 yr of using a rye cover crop in a sweet corn and green bean (Phaseolus vulgaris L.) rotation with spring tillage. In one of their treatments they removed all the cover crop shoot material before spring tillage, demonstrating that much of the effect of the rye cover crop on soil structure was due mostly to the cover crop roots. To further investigate the effect of cover crop roots they made measurements below the plow layer (0.30-0.37 $\mathrm{m})$ in the sixth year of the study and showed that cover crop roots decreased bulk density and increased capillary porosity and hydraulic conductivity relative to the no cover control. Williams and Weil (2004) also presented evidence that cover crop roots can 
improve subsequent cash crop root growth in silt loam soils with compacted plowpans by increasing macroporosity in the compacted soil layers. In their study, they used the minirhizotron camera technique to observe soybean roots growing through the plowpans in root channels created by decomposing cover crop roots of forage radish (Raphanus sativus L.).

\section{Soil Water Status}

Cover crops decrease soil water content through uptake and transpiration while living and can increase soil water content through increased surface residue cover and infiltration after termination (Wagger and Mengel, 1988; Unger and Vigil, 1998; Qi and Helmers, 2010). Thus, the relative impact of cover crops on soil water available to the following crop depends on cover crop management, timing and amount of precipitation, and total water holding capacity of the root-accessible portion of the soil profile (Frye et al., 1988). Cover crop transpiration and soil drying may be beneficial on heavy soils in wet springs because it may allow for earlier planting of the cash crop (Wagger and Mengel, 1988). In fields with subsurface drainage systems, cover crops can reduce drainage volume during the spring before cash crops are planted (Qi and Helmers, 2010), which can reduce losses of nitrate (Kanwar et al., 2005). Alternately, in dry years on coarse-textured soils with low water holding capacity or shallow rooting depth, water use by cover crops may reduce soil water available at planting and may ultimately reduce yields if rainfall does not replenish the water used by the cover crop (Campbell et al., 1984). Once a cover crop has been terminated, however, cover crop residues left on the soil surface can increase surface residue cover, reduce evaporation, and increase soil water contents (Wagger and Mengel, 1988).

Because cover crops increase transpiration when living and decrease evaporation when dead, there have been conflicting reports on the effect of cover crops on available soil water and cash crop yields. Campbell et al. (1984) observed that a rye cover crop terminated with herbicides after corn planting substantially reduced the soil water content of the upper $0.60 \mathrm{~m}$ of the soil profile and reduced corn grain yield on the Coastal Plain in South Carolina. Similarly, Ewing et al. (1991) reported lower soil water contents in the upper $0.15 \mathrm{~m}$ and lower corn yields following a crimson clover (Trifolium incarnatum L.) cover crop in North Carolina on a soil with a root-restricting soil layer. In both of these studies, the negative impact of water use by the cover crop was exaggerated by periods of little or no precipitation and the limited water holding capacity of the rooted soil volume. In contrast to these studies, Moschler et al. (1967) in Virginia observed greater corn yields and soil water contents when rye cover crop residues were left on the soil surface compared with no cover crop, removal of rye residues, or burying rye residues with tillage. Lastly, Clark et al. (1997) in Maryland found that rye, hairy vetch, and rye-hairy vetch mixture cover crops did not significantly deplete soil water contents in the upper $0.20 \mathrm{~m}$ of the soil. After cover crop termination, residues left on the soil surface conserved soil water later in the growing season and contributed to corn yield increases. They also showed that the greater residue cover produced by cover crops terminated closer to the time of corn planting conserved more soil water during corn growth than cover crops terminated earlier. Obviously, the impact of cover crops on soil water content is complicated. From a soil water management perspective, the decision of when to terminate a cover crop depends in part on availability of irrigation, probability of rainfall to replace the water used by the cover crop, and the need for cover crop residues to reduce evaporation from the soil surface. Additionally, unless irrigation is available, cover crops may not be suitable for cropping systems in semiarid regions where annual precipitation sometimes does not replace the water used by the previous cash crop or where the probability for replenishing water used by the cover crop is low (Unger and Vigil, 1998). Obviously, farmers will need location-based guidelines or decision-aide tools to assist them in managing soil water with cover crops.

\section{Nitrogen}

Cover crops can be utilized to manage $\mathrm{N}$ in agricultural soils by altering $\mathrm{N}$ cycling and availability. Cover crops grown during fallow periods in cropping systems change 
the annual patterns of $\mathrm{N}$ uptake and mineralization, reduce downward movement of $\mathrm{NO}_{3}$, retrieve $\mathrm{NO}_{3}$ from deep soil layers, and fix atmospheric $\mathrm{N}_{2}$, if the cover crops are legumes. Ultimately, successful management of $\mathrm{N}$ using cover crops requires that $\mathrm{N}$ availability be synchronized so that inorganic $\mathrm{N}$ is readily available during periods of active uptake by cash crops and minimally available during periods when cash crops are not growing to reduce losses of $\mathrm{N}$ to air and water. Various aspects of the relationship between cover crops and $\mathrm{N}$ have been discussed in a number of previous reviews (Meisinger et al., 1991; Wagger et al., 1998; Dabney et al., 2001; Thorup-Kristensen et al., 2003). This discussion will examine how cover crops reduce losses of $\mathrm{N}$ from soil and affect $\mathrm{N}$ availability to cash crops.

Soil $\mathrm{N}$, in the form of nitrate $\left(\mathrm{NO}_{3}\right)$, is soluble in water and can be lost from agricultural cropping systems with the downward movement of water through the soil profile. In many agricultural fields, percolating water and $\mathrm{NO}_{3}$ are intercepted by agricultural drainage systems, which rapidly transport water and $\mathrm{NO}_{3}$ offsite to surface waters. In fields without drainage systems, percolating water and $\mathrm{NO}_{3}$ can eventually reach groundwater by continuing downward or reach surface waters by following subsurface flow pathways. The presence of living plants can dramatically reduce leaching losses of $\mathrm{NO}_{3}$ in two ways: (i) by taking it up, which reduces its concentration in the soil solution, and (ii) by taking up water, which reduces the amount of water moving through the soil profile. Large leaching losses of $\mathrm{NO}_{3}$ occur in many cropping systems, in part because there are extended fallow periods during each year when living plants are not removing $\mathrm{NO}_{3}$ and water from the soil, usually from cash crop maturity in fall until crop canopy development the following spring. Cover crops reduce annual leaching losses of $\mathrm{NO}_{3}$ because they extend the period of active $\mathrm{N}$ and water uptake to periods of the year when the cash crops are normally not present. For example, reductions in $\mathrm{NO}_{3}$ leaching losses observed with winter cover crops range from 6 to $94 \%$ (Table 21/2).

The wide range in cover crop $\mathrm{NO}_{3}$ leaching reductions reported resulted from differences in cover crop species, the amount of cover crop growth, the amount of $\mathrm{N}$ in the soil due to either fertilization or mineralization, and the amount of water moving through the soil. For example, nonlegume cover crops usually reduce $\mathrm{NO}_{3}$ leaching losses more than legumes (Tonitto et al., 2006). McCracken et al. (1994) in Kentucky observed that a rye cover crop reduced leaching losses by $94 \%$ whereas

Table 21|2. Literature summary of percent reduction in nitrate $\mathrm{N}$ leaching losses due to winter cover crops (adapted in part from Meisinger et al., 1991).

$\begin{array}{lllc}\text { Reference } & \text { Location } & \text { Cover crop } & \begin{array}{c}\text { Reduction in } \\ \text { N leaching }\end{array} \\ \text { Jones, } 1942 & \text { Alabama } & \text { Oats } & 81 \% \\ \text { Jones, } 1942 & \text { Alabama } & \text { Hairy vetch } & 6 \% \\ \text { Chapman et al. } 1949 & \text { California } & \text { Mustard } & 80 \% \\ \text { Chapman et al. 1949 } & \text { California } & \text { Purple vetch } & 30 \% \\ \text { Martinez and Guirard, } 1990 & \text { France } & \text { Ryegrass } & 63 \% \\ \text { Staver and Brinsfield, 1990 } & \text { Maryland } & \text { Rye } & 77 \% \\ \text { Staver and Brinsfield, 1998 } & \text { Maryland } & \text { Rye } & 80 \% \\ \text { McCracken et al., 1994 } & \text { Kentucky } & \text { Rye } & 94 \% \\ \text { McCracken et al., 1994 } & \text { Kentucky } & \text { Hairy vetch } & 48 \% \\ \text { Wyland et al., } 1996 & \text { California } & \text { Rye } & 65-70 \% \\ \text { Brandi-Dohrn et al., } 1997 & \text { Oregon } & \text { Rye } & 32-42 \% \\ \text { Ritter et al., } 1998 & \text { Delaware } & \text { Rye } & 30 \% \\ \text { Rasse et al., } 2000 & \text { Michigan } & \text { Rye } & 28-68 \% \\ \text { Strock et al., } 2004 & \text { Minnesota } & \text { Rye } & 13 \% \\ \text { Kladivko et al., } 2004 & \text { Indiana } & \text { Winter wheat + less fertilizer } & 61 \% \\ \text { Kaspar et al., } 2007 & \text { lowa } & \text { Rye } & 61 \%\end{array}$


a hairy vetch cover crop reduced leaching by $48 \%$. In other studies, combinations of factors have affected the reductions in $\mathrm{NO}_{3}$ leaching. In a Minnesota study (Strock et al., 2004), which showed a $13 \%$ average reduction in $\mathrm{NO}_{3}$ leaching, the rye cover crop was planted only following the corn phase in a corn-soybean rotation, produced on average 1.4 $\mathrm{Mg} \mathrm{ha}{ }^{-1}$ of shoot dry matter, and in 1 of the $3 \mathrm{yr}$ there was almost no drainage or $\mathrm{NO}_{3}$ loss. In years of low winter precipitation, less water moves downward through soil and more $\mathrm{NO}_{3}$ remains in the soil profile even without a cover crop (Fig. 21/1; Thorup-Kristensen et al., 2003). In contrast to the Minnesota study, Kaspar et al. (2007) in Iowa reported that over 4 yr a winter rye cover crop following both phases of a corn-soybean rotation reduced $\mathrm{NO}_{3}$ loads in tile drainage water by an average of $61 \%$ and produced an average shoot biomass of $1.7 \mathrm{Mg} \mathrm{ha}^{-1}$. In the Iowa study, cumulative annual drainage was always greater than $138 \mathrm{~mm}$ and significant $\mathrm{NO}_{3}$ losses occurred every year. Other studies have shown that combining a winter cover crop with other $\mathrm{N}$ management practices can also effectively reduce $\mathrm{NO}_{3}$ losses. A study in Indiana (Kladivko et al., 2004) reduced $\mathrm{NO}_{3}$ loads by $61 \%$ with a reduction in fertilizer $\mathrm{N}$ rates and a winter wheat cover crop following corn. Thus, when a winter cover crop produces moderate growth and substantial water percolation occurs, cover crops can substantially reduce $\mathrm{NO}_{3}$ losses to drainage water or deep percolation in annual cropping systems.

Living cover crops also have the potential to reduce gaseous losses of $\mathrm{N}$ as $\mathrm{N}_{2}, \mathrm{NO}$, and $\mathrm{N}_{2} \mathrm{O}$, from soil (Davidson et al., 2000). Of these, $\mathrm{N}_{2} \mathrm{O}$ is also important as a greenhouse gas. A number of studies have shown that plant roots can effectively compete with soil microorganisms for available $\mathrm{NO}_{3}$ and reduce soil $\mathrm{NO}_{3}$ concentrations, thus reducing its conversion by soil microorganisms to $\mathrm{N}_{2} \mathrm{O}, \mathrm{NO}$, or $\mathrm{N}_{2}$ during denitrification (Smith and Tiedje, 1979; Haider et al., 1987). Nitrous oxide and NO can also be lost during the aerobic nitrification process (Davidson et al., 2000). Because plants can also take up $\mathrm{NH}_{4}$, they might also be expected to reduce gaseous losses by this aerobic process, but this has not been confirmed. In a controlled environment study, in which swine manure was injected into soil with or without a growing rye cover crop, Parkin et al. (2006) showed that $\mathrm{N}_{2} \mathrm{O}$ emissions were significantly lower with a rye cover crop present. Thus, cover crops, like any living plants, have the potential to reduce gaseous losses of $\mathrm{N}$ through microbial reactions by reducing soil $\mathrm{N}$ availability (Davidson et al., 2000). After cover crops are dead, however, their residues can lose $\mathrm{N}$ through emissions of $\mathrm{NH}_{3}, \mathrm{~N}_{2} \mathrm{O}, \mathrm{NO}$, or $\mathrm{N}_{2}$. Quemada and Cabrera (1997) applied crimson clover residues to the surface of soil cores and measured maximum losses of $\mathrm{NH}_{3}$ and $\mathrm{N}_{2} \mathrm{O}$ of 6.0 and $2.6 \%$ of total residue $\mathrm{N}$, respectively under very wet and warm conditions. Emissions of $\mathrm{N}_{2} \mathrm{O}$, 
$\mathrm{NO}$, or $\mathrm{N}_{2}$ resulting from denitrification or nitrification of $\mathrm{N}$ mineralized from cover crop residues would be controlled by the same factors that control gaseous losses of fertilizer $\mathrm{N}$ : $\mathrm{NO}_{3}$ or $\mathrm{NH}_{4}$ availability, carbon availability, and the aeration status (Davidson et al., 2000; Rosecrance et al., 2000). For cover crop shoot residues, anaerobic conditions would be more likely to occur if residues are incorporated with tillage rather than left on the surface. Incorporation of legume cover crop residues with a low $\mathrm{C}$ to $\mathrm{N}$ ratio likely would increase net $\mathrm{N}$ mineralization, increase availability of both $\mathrm{NH}_{4}$ and $\mathrm{NO}_{3}$, and increase gaseous losses of $\mathrm{N}$. The relative importance of denitrification or nitrification to the gaseous losses would depend on the aeration status of the soil (Davidson et al., 2000). Alternately, incorporation of grass cover crop shoot residues with a high $\mathrm{C}$ to $\mathrm{N}$ ratio likely would decrease net $\mathrm{N}$ mineralization, decrease availability of both $\mathrm{NH}_{4}$ and $\mathrm{NO}_{3^{\prime}}$ and decrease gaseous losses of N. For example, Rosecrance et al. (2000) observed that incorporated hairy vetch cover crop residues resulted in greater net $\mathrm{N}$ mineralization and greater $\mathrm{N}_{2} \mathrm{O}$ losses than incorporated rye residues. On the other hand, soil incorporation of cover crop residues probably would make $\mathrm{NH}_{3}$ emissions from residues less likely because $\mathrm{NH}_{3}$ is soluble in water and $\mathrm{NH}_{4}$ binds with soil particles.

Cover crops affect $\mathrm{N}$ availability to cash crops through uptake of inorganic $\mathrm{N}$, fixation of $\mathrm{N}_{2}$ by leguminous cover crops, and decomposition of cover crop residues. Interseeded cover crops or living mulches can directly reduce $\mathrm{N}$ availability for cash crops because they are growing and taking up $\mathrm{N}$ at the same time as the cash crop. Winter or off-season cover crops can also reduce soil $\mathrm{N}$ availability to the cash crop, if the $\mathrm{N}$ taken up by the cover crops still would have been present in the soil when the cash crop needed N. Nitrogen taken up by winter cover crops would not affect $\mathrm{N}$ availability for the cash crops, if the $\mathrm{N}$ taken up would have been lost through leaching or gaseous emissions or if it were replaced by mineralization or fertilization. For example, Thorup-Kristensen et al. (2003) used data from a number of experiments to show that $\mathrm{NO}_{3}-\mathrm{N}$ remaining in the soil with or without cover crops was not different when winter precipitation exceeded $400 \mathrm{~mm}$ (Fig.
21|1). When winter precipitation was less than $400 \mathrm{~mm}$, soil nitrate contents were much higher without a cover crop. Cover crop species also influences the amount of soil $\mathrm{N}$ taken up by the cover crop. In general, nonlegume cover crops take up more soil N than legume cover crops. Ranells and Wagger (1997a) observed that a rye cover crop recovered more ${ }^{15} \mathrm{~N}(39 \%)$ than a crimson clover cover crop (4\%). Shipley et al. (1992) reported that cereal rye and annual ryegrass took up 45 and $27 \%$, respectively, of fall-applied ${ }^{15} \mathrm{~N}$, whereas hairy vetch and crimson clover only recovered $8 \%$.

Cover crops can also have a positive impact on $\mathrm{N}$ availability by increasing the input of $\mathrm{N}$ into cropping systems through $\mathrm{N}_{2}$ fixation by leguminous cover crops. Legumes will also take up $\mathrm{N}$ from the soil, but their growth is not limited by low soil $\mathrm{N}$ levels as are nonleguminous cover crops. Unfortunately, legumes generally do not grow rapidly in cool fall or winter weather and grow much better after the weather warms in the spring. Power and Zachariassen (1993) reported that there were considerable differences among eight legumes in $\mathrm{N}_{2}$ fixation at soil temperatures of 10,20 , and $30^{\circ} \mathrm{C}$ and that for half of the legumes $\mathrm{N}_{2}$ fixation at $10^{\circ} \mathrm{C}$ was much lower than that at the other temperatures. There is also considerable variation in legume cover crop growth and $\mathrm{N}_{2}$ fixation among locations and cropping systems depending on climate, soils, planting date, and termination date. For example, Decker et al. (1994) evaluated three legume winter cover crops over seven environments in Maryland and on average the shoots of hairy vetch, Austrian winter pea (Pisum sativum L.), and crimson clover contained 152, 138, and 121 $\mathrm{kg} \mathrm{N} \mathrm{ha}^{-1}$, respectively. In this same study, a winter wheat cover crop accumulated $39 \mathrm{~kg}$ $\mathrm{N} \mathrm{ha}^{-1}$, so we can probably assume that accumulation of $\mathrm{N}$ greater than $39 \mathrm{~kg} \mathrm{~N} \mathrm{ha}^{-1}$ was probably the result of $\mathrm{N}_{2}$ fixation. Hively and Cox (2001) in the colder environment of central New York, however, observed that four legume cover crop species produced only 2 to $35 \mathrm{~kg} \mathrm{~N} \mathrm{ha}^{-1}$ over 2 yr. Whereas, Ebelhar et al. (1984) in Kentucky reported a 2-yr average of $209 \mathrm{~kg} \mathrm{~N} \mathrm{ha}^{-1}$ in shoot biomass of a hairy vetch cover crop compared with $36 \mathrm{~kg} \mathrm{~N} \mathrm{ha}^{-1}$ in a rye cover crop. Thus, in the appropriate cropping system and 
climate, legume winter cover crops can fix significant amounts of $\mathrm{N}$.

In general, when fertilizer $\mathrm{N}$ is applied at planting it is more readily available and a greater proportion is recovered by annual crops than $\mathrm{N}$ contained in plant residues. For example, Harris et al. (1994) using ${ }^{15} \mathrm{~N}$ showed that over 2 yr corn and barley crops took up $40 \%$ and $17 \%$ of the fertilizer and red clover ${ }^{15} \mathrm{~N}$, respectively. However, $47 \%$ of the red clover ${ }^{15} \mathrm{~N}$ remained in the soil, whereas only $17 \%$ of the fertilizer ${ }^{15} \mathrm{~N}$ was found in the soil. Availability to the cash crop of $\mathrm{N}$ taken up or fixed by a cover crop depends on the decomposition rate of cover crop residues. Residue decomposition is affected by many soil, plant, and environmental factors (Parr and Papendick, 1978). One of the main factors affecting decomposition of cover crop residues and release of $\mathrm{N}$ is the $\mathrm{C}$ to $\mathrm{N}$ ratio of the residues. Residues from grass or cereal cover crops have relatively high $\mathrm{C}$ to $\mathrm{N}$ ratios, decompose slowly, and in some cases immobilize $\mathrm{NO}_{3}$ already present in the soil (Wagger, 1989b; Rosecrance et al., 2000). Legumes have lower $\mathrm{C}$ to $\mathrm{N}$ ratios than nonlegumes, decompose more quickly, and release or mineralize more N (Wagger, 1989a; Ruffo and Bollero, 2003). Using surface-applied ${ }^{15} \mathrm{~N}$-labeled cover crop residues Ranells and Wagger (1997a) showed that averaged over 2 yr corn recovered $14 \%$ of crimson clover $\mathrm{N}$ compared with only $4 \%$ of a rye cover crop $\mathrm{N}$. The greater $\mathrm{N}$ availability of legume cover crops is also reflected in the $\mathrm{N}$ fertilizer response of corn following a rye or hairy vetch winter cover crop (Fig. 2112; Miguez and Bollero, 2006). Miguez and Bollero (2006) showed that at the $0 \mathrm{~kg} \mathrm{~N} \mathrm{ha}^{-1}$ fertilizer rate, the hairy vetch cover crop had greater corn yield than either the rye or no cover crop treatment indicating greater $\mathrm{N}$ availability. In contrast, the rye cover crop treatment had a lower corn yield than the no cover crop treatment at the $0 \mathrm{~kg} \mathrm{~N} \mathrm{ha}{ }^{-1}$ fertilizer rate, indicating that the rye cover crop probably immobilized soil N. In their study, increasing $\mathrm{N}$ fertilizer eventually eliminated the yield difference between the rye and the no cover crop treatment, but not between the rye and hairy vetch treatments. They concluded that factors other than $\mathrm{N}$ availability were involved. Ranells and Wagger (1997b) have suggested planting grass and legume cover crop species in bicultures or mixtures to reduce the $\mathrm{C}$ to $\mathrm{N}$ ratio of the residues and increase the rate of residue decomposition and $\mathrm{N}$ release. Another approach to managing the $\mathrm{C}$ to $\mathrm{N}$ ratio of cover crops is to terminate the cover crop earlier in its life cycle. Wagger (1989a) found that terminating a rye, hairy vetch, or crimson clover cover crop $14 \mathrm{~d}$ earlier resulted in lower $\mathrm{C}$ to $\mathrm{N}$ ratios, lower concentrations of cellulose, hemicellulose, and lignin, faster decomposition, and more released $\mathrm{N}$. In addition to changing the composition of cover crop residues, terminating a cover crop significantly before planting the cash crop allows more time for decomposition of cover crop residues and mineralization of residue N. Optimal synchronization of availability of mineralized residue $\mathrm{N}$ with uptake of $\mathrm{N}$ by the cash crop, however, is difficult to achieve.

Residue incorporation with tillage is another way to increase the rate of residue decomposition and $\mathrm{N}$ release. Tillage breaks or cuts cover crop residues into smaller pieces, covers residues with soil, and improves soil-to-residue contact. This

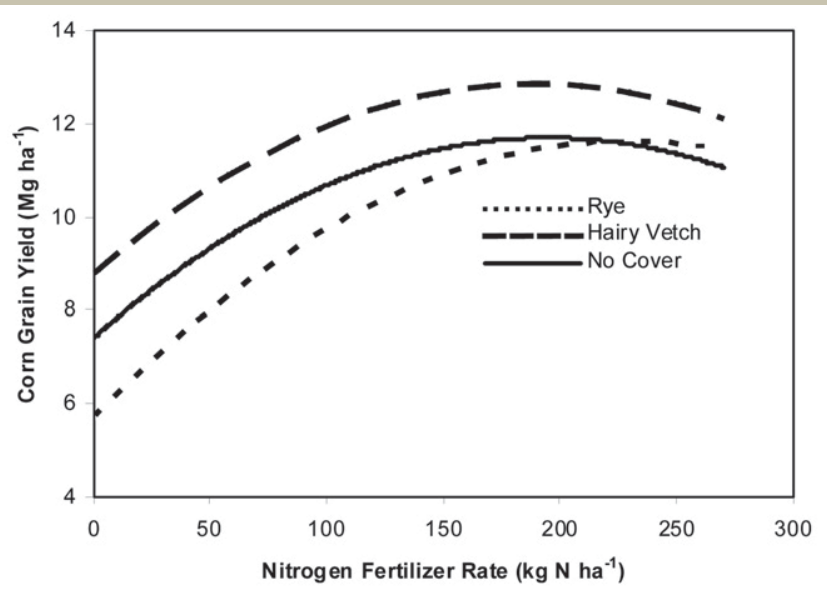

Fig. 21|2. Corn grain yield $\mathrm{N}$ fertilizer response curves for corn following no cover crop, a rye cover crop, or a hairy vetch cover crop in Illinois (adapted from Miguez and Bollero, 2006). 
keeps residues wetter and more accessible to soil microorganisms. Varco et al. (1989) found that in the first year, corn recovered $32 \%$ of the $\mathrm{N}$ in ${ }^{15} \mathrm{~N}$-labeled hairy vetch residues when they were incorporated with tillage compared with only $20 \%$ when residues were left on the surface in no-till. Power et al. (1991) observed that with no added $\mathrm{N}$ fertilizer corn yielded substantially more when a hairy vetch cover crop was incorporated with tillage than when it was terminated with herbicide and remained on the surface. Some questions remain as to the eventual fate of all of the $\mathrm{N}$ in cover crop shoot residues when they are allowed to remain on the soil surface in no-till systems, but incorporation with tillage to increase availability also would negate some of the erosion control and water conservation benefits of cover crop residues.

Cover crops also impact long-term soil $\mathrm{N}$ availability by increasing total soil $\mathrm{N}$ through additions of fixed $\mathrm{N}$ or prevention of $\mathrm{N}$ losses. Few studies have looked at the cumulative effect of winter cover crops on total soil $\mathrm{N}$ when they have been planted every year for multiple years. Because only a portion of cover crop residue $\mathrm{N}$ is mineralized and taken up by the following cash crop, the remaining cover crop $\mathrm{N}$ may be susceptible to loss through leaching or gaseous emissions when it is mineralized (Harris et al., 1994). However, if cover crops are planted every year and fallow periods are avoided, it is likely that most of the cover crop $\mathrm{N}$ will continue to be taken up in later years either by cash crops or cover crops and recycled in the soil-plant system. Then, if inputs of $\mathrm{N}$ exceed outputs, this should gradually increase the total $\mathrm{N}$ content and $\mathrm{N}$ availability of the soil until a new equilibrium is reached. Garwood et al. (1999) calculated an estimated $\mathrm{N}$ balance for cropping systems over $8 \mathrm{yr}$ that indicated that the treatments with winter rye cover crops had accumulated on average an additional $160 \mathrm{~kg} \mathrm{~N}$ ha $^{-1}$ over that time. They hypothesized that the majority of this $\mathrm{N}$ had come from a reduction in $\mathrm{NO}_{3}$ leaching by the cover crop. Gaseous losses of $\mathrm{N}$, however, were not measured in this study and the change in soil organic matter was not significant. Kuo and Jellum (2000) measured an increase in soil organic $\mathrm{N}$ after 8 yr of rye, ryegrass, or hairy vetch cover crops in a corn silage system. Similarly, Sainju and Singh (2008) found that a hairy vetch cover crop increased total soil $\mathrm{N}$ over $3 \mathrm{yr}$ in the $0.0-$ to $0.3-\mathrm{m}$ soil layer. In many soils with high background levels of organic matter and total $\mathrm{N}$, it is difficult to measure changes in total soil $\mathrm{N}$ due to changes in management practices. McCracken et al. (1989) was not able to measure a significant increase in total soil $\mathrm{N}$, but did measure an increase in potential $\mathrm{N}$ mineralization and soil inorganic $\mathrm{N}$ levels in late May after $10 \mathrm{yr}$ of hairy vetch cover crops. Hansen et al. (2000) observed that spring wheat required $27 \mathrm{~kg} \mathrm{~N} \mathrm{ha}^{-1}$ less fertilizer to obtain the same yield after a perennial ryegrass winter cover crop was discontinued after 24 yr. When they terminated their study, this indirect evidence of increased $\mathrm{N}$ availability had persisted for 4 yr after the cover crop was discontinued. In some cases, however, improved soil $\mathrm{N}$ retention by long-term cover crops may not result in positive changes in soil $\mathrm{N}$ status, but instead may increase cash crop yield or grain $\mathrm{N}$ content, which would increase $\mathrm{N}$ outputs from the system (Ball Coelho et al., 2005). Thus, long-term cover crop use can change the $\mathrm{N}$ balance of cropping systems by reducing losses, by supplying fixed $\mathrm{N}$, and by increasing total soil N. Eventually, as the system comes to equilibrium, $\mathrm{N}$ availability to the cash crop may increase. Further research examining $\mathrm{N}$ budgets, gaseous emissions, and changes in total soil $\mathrm{N}$ of cropping systems with cover crops are needed to better understand the cycling of $\mathrm{N}$ in these systems, which should improve soil productivity and management.

\section{Soil Organic Carbon}

Soil productivity is closely linked to soil organic matter (SOM) and its primary component soil organic carbon (SOC). Sequestration of $\mathrm{C}$ in SOM is also an important approach for reducing the concentration of $\mathrm{CO}_{2}$ in the atmosphere (Lal et al., 1999). Soil organic matter, which includes soil humus and all the plant, animal, and microbial residues in the soil, is generally assumed to be 50 to $58 \%$ C by mass (Nelson and Sommers, 1996). In general, SOC increases when inputs of plant residue $C$ to the soil are greater than $C$ losses through 
decomposition, erosion, and leaching (Huggins and Fuchs, 1997; Paustian et al., 1997).

Because cover crops are normally grown during fallow periods of cropping systems, the addition of cover crops to a cropping system can increase total residue $C$ inputs to soil and has the potential to increase SOC (Karlen and Cambardella, 1996; Lal et al., 1999; Jarecki and Lal, 2003). Similarly, the rate at which cover crop residues decompose also affects the balance between losses and inputs of $\mathrm{C}$ into soil. Cover crop residue decomposition depends primarily on temperature, water content, biochemical constituents, residue quantity, $\mathrm{C}$ to $\mathrm{N}$ ratio, and soil contact. Kuo et al. (1997) reported that SOC half-lives for rye, hairy vetch, and annual ryegrass were similar and averaged $31 \mathrm{~d}$ and $57 \mathrm{~d}$ in $2 \mathrm{yr}$ when residues were buried $15 \mathrm{~cm}$ below the soil surface in mesh bags, before planting corn. They attributed the slower decomposition in 1 of the $2 \mathrm{yr}$ to wetter soils and lower temperature. Although hairy vetch had lower shoot $\mathrm{C}$ to $\mathrm{N}$ ratios than ryegrass or rye, this did not affect the observed decay rate, which probably indicates that $\mathrm{N}$ was not limiting and that other factors such as lignin concentration of residues or environmental conditions limited the decomposition rate. In contrast, Ruffo and Bollero (2003) reported that hairy vetch decomposed more rapidly than rye and that the decomposition rate of both responded to water content and temperature.

Cover crops have been used successfully to increase soil C (Table 21/3) especially in locations with mild winters that allow substantial cover crop growth (Beale et al., 1955; Patrick et al., 1957; Utomo et al., 1990; Kuo et al., 1997; Nyakatawa et al., 2001; Sainju et al., 2002). In some of these studies, cover crop residues were incorporated with tillage (Beale et al., 1955; Patrick et al., 1957; Kuo et al., 1997; Sainju et al., 2002). As mentioned earlier, however, soil incorporation or more extensive tillage can increase the relative rate of cover crop decomposition and reduce the retention of cover crop C in soil. Beale et al. (1955) reported that SOM was $28 \%$ higher after $10 \mathrm{yr}$ of a vetch and rye cover crop with mulch tillage compared with cover crops and moldboard plow tillage. In spite of this evidence for increases in soil $C$ and residue $C$ inputs with cover crops, it is often difficult to measure a change in SOC in cropping systems to which cover crops have been added. This is partly because it is difficult to measure small changes in SOC in field soils with relatively high background SOC levels and large variations in SOC with depth and terrain (Kaspar et al., 2006). Additionally, cover crops may not produce large amounts of biomass in some locations or climates and cover crop biomass may be a relatively small percentage of the total biomass produced in some cropping systems like continuous corn. For example, Eckert (1991) in Ohio was not able to detect an increase in soil $\mathrm{C}$ with a rye cover crop in no-till continuous corn or corn-soybean rotations. Duiker and Hartwig (2004) reported similar SOC levels in a crownvetch (Coronilla varia L.) living mulch treatment and the control after 13 yr. They concluded that severe suppression of the crownvetch living mulch to reduce competition with the corn crop had also reduced the soil $\mathrm{C}$ inputs and the SOC benefits. Similarly, Utomo et al. (1990) observed no change in soil C with a rye cover crop in either no-till or conventional tillage, but measured an increase with a hairy vetch cover crop in no-till, which produced more biomass than rye in a $0 \mathrm{~N}$ treatment. Mendes et al. (1999) found that red clover or triticale ( $\times$ Triticosecale Wittmack) winter cover crops did not increase soil $\mathrm{C}$ in a tilled vegetable production system.

Table 21|3. Cover crop increases in soil organic matter (SOM) or soil organic carbon (SOC).

$\begin{array}{llllc}\text { Reference } & \text { Location } & \text { Cover crop } & \text { Depth of sample } & \begin{array}{c}\text { Increase in SOM } \\ \text { or SOC† }\end{array} \\ \text { Beale et al. (1955) } & \text { South Carolina } & \text { Vetch and rye } & 0.13 \mathrm{~m} & 31 \% \\ \text { Patrick et al. (1957) } & \text { Louisiana } & \text { Hairy vetch } & 0.07 \mathrm{~m} & 85 \% \\ \text { Kuo et al. (1997) } & \text { Washington } & \text { Rye } & 0.30 \mathrm{~m} & 7 \% \dagger \\ \text { Sainju et al. (2002) } & \text { Georgia } & \text { Rye } & 0.20 \mathrm{~m} & 12 \% \dagger \\ \text { Villamil et al. (2006) } & \text { Illinois } & \text { Rye and hairy vetch } & 0.30 \mathrm{~m} & 9 \%\end{array}$

† Soil organic carbon. 


\section{Soil Chemical Properties}

Aside from the impacts of cover crops on $\mathrm{C}$ and $\mathrm{N}$ cycling in soil, little is known about the effect of cover crops on other nutrients or soil pH. Nyakatawa et al. (2001) reported no effect of a winter rye cover crop in a continuous cotton system on soil $\mathrm{pH}$ after two cycles compared with a winter fallow treatment. Eckert (1991) observed that a rye winter cover crop increased soil $\mathrm{pH}$ by a small amount in two of three cropping systems where corn followed rye and concluded that this was due to rye's assimilation of $\mathrm{NH}_{4}$ and not a relocation of Ca. Eckert (1991) also reported that rye increased exchangeable $\mathrm{K}$ concentrations in the surface $0.05 \mathrm{~m}$, presumably by accumulating $\mathrm{K}$ from the soil and depositing the K-containing shoot and root residues on the soil surface and in the upper $0.05 \mathrm{~m}$. The rye cover crop did not significantly affect soil concentrations of C, $\mathrm{P}, \mathrm{Ca}$, or $\mathrm{Mg}$ in these studies.

\section{Soil Biology}

Cover crops increase the potential for macroand microfaunal activity in soils because they increase the total inputs of organic material to soils, they increase the length of time each year that plants are growing and inputting $C$ into the soil, and they moderate changes in soil temperature and water content by increasing surface cover. For example, Mele and Carter (1999) concluded that crop residues on the soil surface and no soil disturbance support higher densities and weight of some species of earthworms because of increased water content of surface layers, food sources at the surface, and retention of burrows. Reeleder et al. (2006) reported higher densities of earthworms, predominately Aporrectodea turgida, in 1 of 2 yr of their study after 8 yr of a rye cover crop. Averaged across tillage, the rye treatment had 33.3 worms $\mathrm{m}^{-2}$ compared with 12.8 worms $\mathrm{m}^{-2}$ in the no rye treatment. They postulated that earthworm populations may have been higher in the rye treatment because of increased availability of water. Also, in this same study populations of microarthropods were generally higher with a rye cover crop than without, but the total population of soil fungi was unaffected by cover crops. Ketterings et al. (1997) artificially altered earthworm populations and determined that earthworms increased stability of aggregates $>1.0 \mathrm{~mm}$ diameter following a cereal rye-hairy vetch cover crop. They also reported that earthworms exhibited a preference for organic materials high in $\mathrm{N}$, increased the storage of $\mathrm{C}$ and $\mathrm{N}$ in aggregates, and facilitated the decomposition of coarse organic material deposited on the soil surface.

Cover crops can also increase the potential for microfaunal activity. Reddy et al. (2003) reported that after 3 yr with crimson clover or cereal rye cover crops soil had greater total bacterial and fungal propagule density and fluorescein diacetate hydrolytic activity (FDA) than the soil without a cover crop. The FDA assay is a measure of the soil enzyme esterase and is used as an indicator of microbial activity and biomass. In their study, the crimson clover cover crop had a greater stimulatory effect on soil biology than cereal rye. The authors speculated that the legume cover crop had more readily available amino acids and carbohydrates than the grass cover crops because of a lower C to $\mathrm{N}$ ratio. Lundquist et al. (1999) reported on the short-term (42 d) effects of cereal rye incorporation in contrasting vegetable management systems. Their results indicated that following rye incorporation, counts of active bacteria increased 24 to $52 \%$ in the first $7 \mathrm{~d}$ and populations of bacterialfeeding nematodes increased 400 to $600 \%$ between 7 and $14 \mathrm{~d}$. Active fungal hyphal lengths and fungal-feeding nematodes were less responsive to rye incorporation during the 42 -d period.

Considerable evidence exists regarding the control of weeds, plant pathogens, and nematodes by chemical substances released from cover crop plants or from their residues into the soil (Inderjit and Keating, 1999). Chemicals released during decomposition of cover crop residues may be released in their unaltered form or may be altered or transformed by soil microorganisms. As with many of the effects of cover crops on soil properties that have been discussed, these chemicals released into the soil are common to many plant species and not just cover crops. These substances are known as allelochemicals and they can have positive or negative effects on plants or soil organisms (Inderjit and Keating, 1999). These compounds are primarily secondary 
metabolites and include phenolics, terpenoids, alkaloids, steroids, polyacetylenes, and essential oils (Inderjit and Keating, 1999). Inderjit and Keating (1999), however, also reported that amino acids and organic acids have been shown to possess allelopathic potential, although clear effects on biological activity have not always been proven. In any case, cover crops offer unique opportunities for using allelochemicals to control weeds, pathogens, and nematodes in agricultural cropping systems because they can be grown during the fallow periods in these systems.

Cover crops that are members of the Poaceae and Cruciferae families have the potential to be used as biofumigants to control plant parasitic nematodes and soil fungi. Brassicas contain glucosinolates that undergo hydrolysis to produce compounds with broad biocidal activity (Brown and Morra, 1997). Kirkegaard and Sarwar (1998) quantified levels of glucosinolates in 65 brassica species and reported that total glucosinolates on a per unit area basis ranged from 0.8 to $45.3 \mathrm{mmol} \mathrm{m} \mathrm{m}^{-2}$ when sampled at the midflowering growth stage. They concluded that the variation in biomass and glucosinolate compounds and their concentrations in various plant parts provide opportunities for enhanced selection to increase their biofumigation potential. Sarwar et al. (1998) showed that the compounds released from Brassicas suppressed five cereal root pathogens in laboratory tests. Similarly, Potter et al. (1998) found that leaf tissue of a variety of Brassica species incorporated into soil was highly nematicidal. McBride et al. (2000) also found that incorporated cereal rye significantly suppressed nematode activity. They had hypothesized that low molecular weight organic acids were responsible for the nematode-suppressing qualities of rye and they detected organic acids in soil solution shortly after incorporation of fresh rye foliage. The rapid degradation of the organic acids in the soil, however, led them to conclude that these acids probably were not solely responsible for suppressing the nematodes.

Understanding the chemical mechanisms for weed suppression by cover crops is challenging. Barnes and Putnam (1986) in a greenhouse study reported that rye residues and their aqueous extracts lowered emergence and radicle elongation for several species and that shoot residues were more effective than root residues at inhibiting lettuce (Lactuca sativa L.) germination. Liebl et al. (1992) reported that cereal rye provided excellent weed control, with or without herbicides, and concluded that the weed suppression of the rye cover crop could have been caused by an allelopathic effect of decaying rye residues or the physical presence of the rye mulch on the soil surface or both. Similar to the range of allelochemical concentrations found among Brassica spp., Burgos et al. (1999) found that concentrations of the allelochemicals in rye DIBOA [2,4-dihydroxy-1,4-(2H)-benzoxazine-3one] and BOA [2-( $3 H)$-benzoxazolinone], both hydroxamic acids, ranged from 137 to $1469 \mu \mathrm{g} \mathrm{g}^{-1}$ dry tissue among eight cultivars grown in the field. They also reported data from a parallel greenhouse study that demonstrated that concentrations of hydroxamic acid peaked $60 \mathrm{~d}$ after planting rye. Although the allelochemicals produced by rye and other cover crops may provide beneficial suppression of weeds, these same chemicals may also be responsible for yield decreases of cash crops following cover crops. For example, both Johnson et al. (1998) and Raimbault et al. (1990) reported reductions in either grain or silage yields when corn was planted immediately after terminating a rye cover crop with herbicide. In later studies, Raimbault et al. (1991) showed that corn planted $14 \mathrm{~d}$ after rye cover crop termination produced $9 \%$ higher silage yields than corn planted immediately after rye was terminated. They hypothesized that one of many possible explanations could be that the extra time allowed any allelochemicals produced by the rye to be dissipated or denatured.

\section{Summary}

Inserting cover crops into fallow periods and spaces in cropping systems is a beneficial soil management practice. Cover crops can protect the soil from erosion, reduce losses of $\mathrm{N}$ and $\mathrm{P}$, increase soil $\mathrm{C}$, reduce runoff, inhibit pests, and support beneficial soil fauna. Although cover crops have the potential to maintain and enhance soil productivity and to reduce offsite impacts of $\mathrm{N}, \mathrm{P}$, sediment, and greenhouse gases $\left(\mathrm{CO}_{2}\right.$ and $\left.\mathrm{N}_{2} \mathrm{O}\right)$, they are not widely used in most agricultural systems (Singer et al., 
2007). Incorporating cover crops into cropping systems requires time, money, inputs, machinery, labor, and modifications of current practices without immediate financial return to the farmer. Improvements in soil productivity resulting from cover crops may require many years before benefits are detectable. Additionally, availability of cover crop management information, cover crop seed, and custom planting and spraying services need to be improved to facilitate adoption of cover crops in grain, oilseed, and fiber cropping systems. However, if farmers are given financial and productivity incentives to grow cover crops, farmers, crop consultants, and scientists should be able to overcome these management, supply, and service problems relatively quickly. Therefore, scientists need to demonstrate to farmers with long-term integrated studies that maintaining or enhancing soil productivity with cover crops provides long-term financial benefits. Additionally, scientists need to demonstrate to nonfarmers that providing incentives for widespread adoption of cover crops could provide valuable ecosystem services and improvement of water quality, while still maintaining current levels of food, biomass, and fiber production.

\section{References}

Angle, J.S., G. Mc Clung, M.S. Mc Intosh, P.M. Thomas, and D.C. Wolf. 1984. Nutrient losses in runoff from conventional and no-till corn watersheds. J. Environ. Qual. 13:431-435.

Ball-Coelho, B.R., R.C. Roy, and C.J. Swanton. 2000. Tillage and cover crop impacts on aggregation of a sandy soil. Can. J. Soil Sci. 80:363-366.

Ball Coelho, B.R., R.C. Roy, and A.J. Bruin. 2005. Longterm effects of late-summer overseeding of winter rye on corn grain yield and nitrogen balance. Can. J. Plant Sci. 85:543-554.

Barnes, J.P., and A.R. Putnam. 1986. Evidence for allelopathy by residues and aqueous extracts of rye (Secale cereale). Weed Sci. 34:384-390.

Beale, O.W., G.B. Nutt, and T.C. Peele. 1955. The effects of mulch tillage on runoff, erosion, soil properties, and crop yields. Soil Sci. Soc. Am. Proc. 19:244-247.

Bechmann, M.E., P.J.A. Kleinman, A.N. Sharpley, and L.S. Saporito. 2005. Freeze-thaw effects on phosphorus loss in runoff from manured and catch-cropped soils. J. Environ. Qual. 34:2301-2309.

Benoit, R.E., N.A. Willits, and W.J. Hanna. 1962. Effect of rye winter cover crop on soil structure. Agron. J. 54:419-420.

Brandi-Dohrn, F.M., M. Hess, J.S. Selker, R.P. Dick, S.M. Kauffman, and D.D. Hemphill, Jr. 1997. Nitrate leaching under a cereal rye cover crop. J. Environ. Qual. 26:181-188.

Brown, L.C., and L.D. Norton. 1994. Surface residue effects on soil erosion from ridges of different soils and formation. Trans. ASAE 37:1515-1524.
Brown, P.D., and M.J. Morra. 1997. Control of soil-borne plant pests using glucosinolate-containing plants. Adv. Agron. 61:167-231.

Burgos, N.R., R.E. Talbert, and J.D. Mattice. 1999. Cultivar and age differences in the production of allelochemicals by Secale cereale. Weed Sci. 47:481-485.

Campbell, R.B., D.L. Karlen, and R.E. Sojka. 1984. Conservation tillage for maize production in the U.S. Southeastern Coastal Plain. Soil Tillage Res. 4:511-529.

Chapman, H.D., G.F. Liebig, and D.S. Rayner. 1949. A lysimeter investigation of nitrogen gains and losses under various systems of covercropping and fertilization and a discussion of error sources. Hilgardia 19:57-95.

Clark, A.J., A.M. Decker, J.J. Meisinger, and M.S. McIntosh. 1997. Kill date of vetch, rye, and a vetch-rye mixture: II. Soil moisture and corn yield. Agron. J. 89:434-441.

Dabney, S.M. 1998. Cover crop impacts on watershed hydrology. J. Soil Water Conserv. 53:207-213.

Dabney, S.M., J.A. Delgado, and D.W. Reeves. 2001. Using winter cover crops to improve soil and water quality. Commun. Soil Sci. Plant Anal. 32:1221-1250.

Dapaah, H.K., and T.J. Vyn. 1998. Nitrogen fertilization and cover crop effects on soil structural stability and corn performance. Commun. Soil Sci. Plant Anal. 29:2557-2569.

Davidson, E.A., M. Keller, H.E. Erickson, L.V. Verchot, and E. Veldkamp. 2000. Testing a conceptual model of soil emissions of nitrous and nitric oxides. Bioscience 50:667-680.

Decker, A.M., A.J. Clark, J.J. Meisinger, F.R. Mulford, and M.S. McIntosh. 1994. Legume cover crop contributions to no-tillage corn production. Agron. J. 86:126-135.

Degens, B.P., G.P. Sparling, and L.K. Abbott. 1996. Increasing the length of hyphae in a sandy soil increases the amount of water-stable aggregates. Appl. Soil Ecol. 3:149-159.

Duiker, S.W., and N.L. Hartwig. 2004. Living mulches of legumes in imidazolinone-resistant corn. Agron. J. 96:1021-1028.

Ebelhar, S.A., W.W. Frye, and R.L. Blevins. 1984. Nitrogen from legume cover crops for no-tillage corn. Agron. J. 76:51-55.

Eckert, D.J. 1991. Chemical attributes of soils subjected to no-till cropping with rye cover crops. Soil Sci. Soc. Am. J. 55:405-409.

Ewing, R.P., M.G. Wagger, and H.P. Denton. 1991. Tillage and cover crop management effects on soil water and corn yield. Soil Sci. Soc. Am. J. 55:1081-1085.

Flanagan, D.C. 2002. Erosion. In R. Lal (ed.) Encyclopedia of soil science. Marcel Dekker, Inc., New York.

Foster, G.R., C.B. Johnson, and W.C. Moldenhauer. 1982 Critical slope lengths for unanchored cornstalk and wheat straw residue. Trans. ASAE 25:935-939, 947.

Frye, W.W., R.L. Blevins, M.S. Smith, S.J. Corak, and J.J. Varco. 1988. Role of annual legume cover crops in efficient use of water and nitrogen. p. 129-154. In W.L. Hargrove (ed.) Cropping strategies for the efficient use of water and nitrogen. ASA, CSSA, and SSSA, Madison, WI.

Garwood, T.W.D., D.B. Davies, and A.R. Hartley. 1999. The effect of winter cover crops on yield of the following spring crops and nitrogen balance in a calcareous loam. J. Agric. Sci. 132:1-11.

Haider, K., A. Mosier, and O. Heinemeyer. 1987. The effect of growing plants on denitrification at high soil nitrate concentrations. Soil Sci. Soc. Am. J. 51:97-102.

Hansen, E.M., J. Djurhuus, and K. Kristensen. 2000. Nitrate leaching as affected by introduction or discontinuation of cover crop use. J. Environ. Qual. 29:1110-1116.

Harris, G.H., O.B. Hesterman, E.A. Paul, S.E. Peters, and R.R. Janke. 1994. Fate of legume and fertilizer nitro- 
gen-15 in a long-term cropping systems experiment. Agron. J. 86:910-915.

Hively, W.D., and W.J. Cox. 2001. Interseeding cover crops into soybean and subsequent corn yields. Agron. J. 93:308-313.

Huggins, D.R., and D.J. Fuchs. 1997. Long-term N management effects on corn yield and soil $\mathrm{C}$ of an Aquic Haplustoll in Minnesota. p. 121-128. In E.A. Paul et al. (ed.) Soil organic matter in temperate ecosystems: Long-term experiments in North America. CRC Press, Boca Raton, FL.

Inderjit, and K.I. Keating. 1999. Allelopathy: Principles, procedures, processes, and promises for biological control. Adv. Agron. 67:141-231.

Jarecki, M.K., and R. Lal. 2003. Crop management for soil carbon sequestration. Crit. Rev. Plant Sci. 22:471-502.

Johnson, T.J., T.C. Kaspar, K.A. Kohler, S.J. Corak, and S.D. Logsdon. 1998. Oat and rye overseeded into soybean as fall cover crops in the upper Midwest. J. Soil Water Conserv. 53:276-279.

Jones, R.J. 1942. Nitrogen losses from Alabama soils in lysimeters as influenced by various systems of green manure crop management. Agron. J. 34:574-585.

Kanwar, R.S., R.M. Cruse, M. Ghaffarzadeh, A. Bakhsh D.L. Karlen, and T.B. Bailey. 2005. Corn-soybean and alternative cropping systems effects on $\mathrm{NO}_{3}-\mathrm{N}$ leaching losses in subsurface drainage water. Appl. Eng. Agric. 21:181-188.

Karlen, D.L., and C.A. Cambardella. 1996. Conservation strategies for improving soil quality and organic matter storage. p. 395-420. In M.R. Carter and B.A. Stewart (ed.) Structure and organic matter storage in agricultural soils. Advances in Soil Science. CRC Press Inc., New York.

Kaspar, T.C., J.K. Radke, and J.M. Laflen. 2001. Small grain cover crops and wheel traffic effects on infiltration, runoff, and erosion. J. Soil Water Conserv. 56:160-164.

Kaspar, T.C., T.B. Parkin, D.B. Jaynes, C.A. Cambardella D.W. Meek, and Y.S. Jung. 2006. Examining changes in soil organic carbon with oat and rye cover crops using terrain covariates. Soil Sci. Soc. Am. J. 70:1168-1177.

Kaspar, T.C., D.B. Jaynes, T.B. Parkin, and T.B. Moorman. 2007. Rye cover crop and gamagrass strip effects on $\mathrm{NO}_{3}$ concentration and load in tile drainage. J. Environ. Qual. 36:1503-1511.

Ketterings, Q.M., J.M. Blair, and J.C.Y. Marinissen. 1997. Effects of earthworms on soil aggregate stability and carbon and nitrogen storage in a legume cover crop agroecosystem. Soil Biol. Biochem. 29:401-408.

Kirkegaard, J.A., and M. Sarwar. 1998. Biofumigation potential of brassicas. I. Variation in glucosinolate profiles of diverse field-grown brassicas. Plant Soil 201:71-89.

Kladivko, E.J., J.R. Frankenberger, D.B. Jaynes, D.W. Meek, B.J. Jenkinson, and N.R. Fausey. 2004. Nitrate leaching to subsurface drains as affected by drain spacing and changes in crop production system. J. Environ. Qual. 33:1803-1813.

Kuo, S., U.M. Sainju, and E.J. Jellum. 1997. Winter cover crop effects on soil organic carbon and carbohydrate in soil. Soil Sci. Soc. Am. J. 61:145-152.

Kuo, S., and E.J. Jellum. 2000. Long-term winter cover cropping effects on corn (Zea mays L.) production and soil nitrogen availability. Biol. Fertil. Soils 31:470-477.

Laflen, J.M., G.R. Foster, and C.A. Onstad. 1985. Simulation of individual-storm soil loss for modeling the impact of soil erosion on crop productivity. p. 285-295. In S.A. El-Swaify et al. (ed.) Soil erosion and conservation. Soil and Water Conserv. Soc., Ankeny, IA.

Lal, R., J.M. Kimble, R.F. Follett, and C.V. Cole. 1999. The potential of U.S. cropland to sequester carbon and mitigate the greenhouse effect. Ann Arbor Press, Chelsea, MI.
Langdale, G.W., R.A. Leonard, and A.W. Thomas. 1985 Conservation practice effects on phosphorus losses from southern piedmont watersheds. J. Soil Water Conserv. 40:157-161.

Langdale, G.W., and R.L. Blevins. D.L. Karlen, D.K. McCool, M.A. Nearing, E.L. Skidmore, A.W. Thomas, D.D, Tyler, and J.R. Williams. 1991. Cover crop effects on soil erosion by wind and water. p. 15-22. In W.L. Hargrove (ed.) Cover crops for clean water. Proc. Int. Conf., Jackson, TN. 9-11 April 1991. Soil and Water Conserv. Soc., Ankeny, IA.

Lattanzi, A.R., L.D. Meyer, and M.F. Baumgardner. 1974. Influences of mulch rate and slope steepness on interrill erosion. Soil Sci. Soc. Am. J. 38:946-950.

Liebl, R., F.W. Simmons, L.M. Wax, and E.W. Stoller. 1992 Effect of rye (Secale cereale) mulch on weed-control and soil-moisture in soybean (Glycine max). Weed Technol. 6:838-846.

Lundquist, E.J., L.E. Jackson, K.M. Scow, and C. Hsu. 1999. Changes in microbial biomass and community composition, and soil carbon and nitrogen pools after incorporation of rye into three California agricultural soils. Soil Biol. Biochem. 31:221-236.

Mamo, M., and G.D. Bubenzer. 2001. Detachment rate, soil erodibility, and soil strength as influenced by living plant roots. Part II: Field study. Trans. ASAE 44:1175-1181.

Martinez, J., and G. Guiraud. 1990. A lysimeter study of the effects of a ryegrass catch crop, during a winterwheat maize rotation, on nitrate leaching and on the following crop. J. Soil Sci. 41:5-16.

McBride, R.G., R.L. Mikkelsen, and K.R. Barker. 2000 The role of low molecular weight organic acids from decomposing rye in inhibiting root-knot nematode populations in soil. Appl. Soil Ecol. 15:243-251.

McCracken, D.V., S.J. Corak, M.S. Smith, W.W. Frye, and R.L. Blevins. 1989. Residual effects of nitrogen fertilization and winter cover cropping on nitrogen availability. Soil Sci. Soc. Am. J. 53:1459-1464.

McCracken, D.V., M.S. Smith, J.H. Grove, R.L. Blevins, and C.T. MacKown. 1994. Nitrate leaching as influenced by cover cropping and nitrogen source. Soil Sci. Soc. Am. J. 58:1476-1483.

Meisinger, J.J., W.L. Hargrove, R.L. Mikkelsen, J.R. Williams, and V.W. Benson. 1991. Effects of cover crops on groundwater quality. p. 57-68. In W.L. Hargrove (ed.) Cover crops for clean water. Proc. Int. Conf., Jackson, TN. 9-11 April 1991. Soil and Water Conserv. Soc., Ankeny, IA.

Mele, P.M., and M.R. Carter. 1999. Impact of crop management factors in conservation tillage farming on earthworm density, age structure and species abundance in south-eastern Australia. Soil Tillage Res. 50:1-10.

Mendes, I.C., A.K. Bandick, R.P. Dick, and P.J. Bottomley. 1999. Microbial biomass and activities in soil aggregates affected by winter cover crops. Soil Sci. Soc. Am. J. 63:873-881.

Miguez, F.E., and G.A. Bollero. 2006. Winter cover crops in Illinois: Evaluation of ecophysiological characteristics of corn. Crop Sci. 46:1536-1545.

Moschler, W.W., G.M. Shear, D.L. Hallok, R.D. Sears, and G.D. Jones. 1967. Winter cover crops for sod-planted corn: Their selection and management. Agron. J. 59:547-551

Mutchler, C.K., and L.L. McDowell. 1990. Soil loss from cotton with winter cover crops. Trans. ASAE 33:432-436.

Nelson, D.W., and L.E. Sommers. 1996. Total carbon, organic carbon, and organic matter. p. 961-1010. In D.L. Sparks et al. (ed.) Methods of soil analysis. Part 3. Chemical methods. SSSA Book Ser. 5. SSSA, Madison, WI.

Nyakatawa, E.Z., K.C. Reddy, and K.R. Sistani. 2001. Tillage, cover cropping, and poultry litter effects on 
selected soil chemical properties. Soil Tillage Res. 58:69-79.

Parkin, T.B., T.C. Kaspar, and J.W. Singer. 2006. Cover crop effects on the fate of $\mathrm{N}$ following soil application of swine manure. Plant Soil 289:141-152.

Parr, J.F., and R.I. Papendick. 1978. Factors affecting the decomposition of crop residues by microorganisms. p. 109-129. In W.R. Oschwald (ed.) Crop residue management systems. ASA, Madison, WI.

Patrick, W.H., Jr., C.B. Haddon, and J.A. Hendrix. 1957. The effect of longtime use of winter cover crops on certain physical properties of Commerce loam. Soil Sci. Soc. Am. J. 21:366-368.

Paustian, K., H.P. Collins, and E.A. Paul. 1997. Management controls on soil carbon. p. 15-49. In E.A. Paul et al. (ed.) Soil organic matter in temperate ecosystems: Long-term experiments in North America. CRC Press, Boca Raton, FL.

Pesant, A.R., J.L. Dionne, and J. Genest. 1987. Soil and nutrient losses in surface runoff from conventional and no-till corn systems. Can. J. Soil Sci. 67:835-843.

Potter, M.J., K. Davies, and A.J. Rathjen. 1998. Suppressive impact of glucosinolates in brassica vegetative tissues on root lesion nematode Pratylenchus neglectus. J. Chem. Ecol. 24:67-80.

Power, J.F., J.W. Doran, and P.T. Koerner. 1991. Hairy vetch as a winter cover crop for dryland corn production. J. Prod. Agric. 4:62-67.

Power, J.F., and J.A. Zachariassen. 1993. Relative nitrogen utilization by legume cover crop species at three soil temperatures. Agron. J. 85:134-140.

Qi, Z., and M.J. Helmers. 2010. Soil water dynamics under winter rye cover crop in central Iowa. Vadose Zone J. 9:53-60.

Quemada, M., and M.L. Cabrera. 1997. Temperature and moisture effects on $\mathrm{C}$ and $\mathrm{N}$ mineralization from surface applied clover residue. Plant Soil 189:127-137.

Raimbault, B.A., T.J. Vyn, and M. Tollenaar. 1990. Corn response to rye cover crop management and spring tillage systems. Agron. J. 82:1088-1093.

Raimbault, B.A., T.J. Vyn, and M. Tollenaar. 1991. Corn response to rye cover crop, tillage methods, and planter options. Agron. J. 83:287-290.

Ram, D.N., M.T. Vittum, and P.J. Zwerman. 1960. An evaluation of certain winter cover crops for the control of splash erosion. Agron. J. 52:479-482.

Ranells, N.N., and M.G. Wagger. 1997a. Nitrogen-15 recovery and release by rye and crimson clover cover crops. Soil Sci. Soc. Am. J. 61:943-948.

Ranells, N.N., and M.G. Wagger. 1997b. Grass-legume bicultures as winter annual cover crops. Agron. J 89:659-665.

Rasse, D.P., J.T. Ritchie, W.R. Peterson, J. Wei, and A.J.M. Smucker. 2000. Rye cover crop and nitrogen fertilization effects on nitrate leaching in inbred maize fields. J. Environ. Qual. 29:298-304.

Reddy, K.N., R.M. Zablotowicz, M.A. Locke, and C.H. Koger. 2003. Cover crop, tillage, and herbicide effects on weeds, soil properties, microbial populations, and soybean yield. Weed Sci. 51:987-994.

Reeleder, R.D., J.J. Miller, B.R.B. Coelho, and R.C. Roy. 2006. Impacts of tillage, cover crop, and nitrogen on populations of earthworms, microarthropods, and soil fungi in a cultivated fragile soil. Appl. Soil Ecol. 33:243-257.

Ritter, W.F., R.W. Scarborough, and A.E.M. Chirnside. 1998. Winter cover crops as a best management practice for reducing nitrogen leaching. J. Contam. Hydrol. 34:1-15.

Rosecrance, R.C., G.W. McCarty, D.R. Shelton, and J.R. Teasdale. 2000. Denitrification and N mineralization from hairy vetch (Vicia villosa Roth) and rye (Secale cereale L.) cover crop monocultures and bicultures. Plant Soil 227:283-290.
Ruffo, M.L., and G.A. Bollero. 2003. Modeling rye and hairy vetch residue decomposition as a function of degree-days and decomposition-days. Agron. J. 95:900-907.

Sainju, U.M., B.P. Singh, and W.F. Whitehead. 2002. Longterm effects of tillage, cover crops, and nitrogen fertilization on organic carbon and nitrogen concentrations in sandy loam soils in Georgia, USA. Soil Tillage Res. 63:167-179.

Sainju, U.M., and B.P. Singh. 2008. Nitrogen storage with cover crops and nitrogen fertilization in tilled and nontilled soils. Agron. J. 100:619-627.

Sarwar, M., J.A. Kirkegaard, P.T.W. Wong, and J.M. Desmarchelier. 1998. Biofumigation potential of brassicas. III. In vitro toxicity of isothiocyanates to soil-borne fungal pathogens. Plant Soil 201:103-112.

Sharpley, A.N., and S.J. Smith. 1991. Effects of cover crops on surface water quality. p. 41-49. In W.L. Hargrove (ed.) Cover crops for clean water. Proc. Int. Conf., Jackson, TN. 9-11 April 1991. Soil and Water Conserv. Soc., Ankeny, IA.

Shipley, P.R., J.J. Messinger, and A.M. Decker. 1992. Conserving residual corn fertilizer nitrogen with winter cover crops. Agron. J. 84:869-876.

Singer, J.W., S.M. Nusser, and C.J. Alf. 2007. Are cover crops being used in the US corn belt? J. Soil Water Conserv. 62:353-358.

Smith, M.S., and J.M. Tiedje. 1979. The effect of roots on soil denitrification. Soil Sci. Soc. Am. J. 43:951-955.

Staver, K.W., and R.B. Brinsfield. 1990. Patterns of soil nitrate availability in corn production systems: implications for reducing groundwater contamination. J. Soil Water Conserv. 45:318-323.

Staver, K.W., and R.B. Brinsfield. 1998. Using cereal grain winter cover crops to reduce groundwater nitrate contamination in the mid-Atlantic coastal plain. J. Soil Water Conserv. 53:230-240.

Strock, J.S., P.M. Porter, and M.P. Russelle. 2004. Cover cropping to reduce nitrate loss through subsurface drainage in the northern U.S. Corn Belt. J. Environ. Qual. 33:1010-1016.

Thorup-Kristensen, K., J. Magid, and L.S. Jensen. 2003. Catch crops and green manures as biological tools in nitrogen management in temperate zones. Adv. Agron. 79:227-302.

Timmons, D.R., R.F. Holt, and J.J. Latterel. 1970. Leaching of crop residues as a source of nutrients in surface runoff water. Water Resour. Res. 6:1367-1375.

Tisdall, J.M., and J.M. Oades. 1979. Stabilization of soil aggregates by the root systems of ryegrass. Aust. J. Soil Res. 17:429-441.

Tonitto, C., M.B. David, and L.E. Drinkwater. 2006. Replacing bare fallows with cover crops in fertilizer-intensive cropping systems: A meta-analysis of crop yield and $\mathrm{N}$ dynamics. Agric. Ecosyst. Environ. 112:58-72.

Unger, P.W., and M.F. Vigil. 1998. Cover crop effects on soil water relationships. J. Soil Water Conserv. 53:200-207.

Utomo, M., W.W. Frye, and R.L. Blevins. 1990. Sustaining soil nitrogen for corn using hairy vetch cover crop. Agron. J. 82:979-983.

Varco, J.J., W.W. Frye, M.S. Smith, and C.T. MacKown. 1989. Tillage effects on nitrogen recovery by corn from a nitrogen-15 labeled legume cover crop. Soil Sci. Soc. Am. J. 53:822-827.

Villamil, M.B., G.A. Bollero, R.G. Darmody, F.W. Simmons, and D.G. Bullock. 2006. No-till corn/soybean systems including winter cover crops: Effects on soil properties. Soil Sci. Soc. Am. J. 70:1936-1944.

Wagger, M.G., and D.B. Mengel. 1988. The role of nonleguminous cover crops in the efficient use of water and nitrogen. p. 115-127. In W.L. Hargrove (ed.) Cropping strategies for efficient use of water and nitrogen. ASA CSSA, and SSSA, Madison, WI. 


\section{Soil Management Practices}

Wagger, M.G. 1989a. Time of desiccation effects on plant composition and subsequent nitrogen release from several winter annual cover crops. Agron. J. 81:236-241.

Wagger, M.G. 1989b. Cover crop management and nitrogen rate in relation to growth and yield of no-till corn. Agron. J. 81:533-538.

Wagger, M.G., M.L. Cabrera, and N.N. Ranells. 1998 Nitrogen and carbon cycling in relation to cover crop residue quality. J. Soil Water Conserv. 53:214-218.

Wander, M.M., S.J. Traina, B.R. Stinner, and S.E. Peters 1994. Organic and conventional management effects on biologically active soil organic matter pools. Soil Sci. Soc. Am. J. 58:1130-1139.

Wendt, R.C., and R.E. Burwell. 1985. Runoff and soil losses for conventional, reduced, and no-till corn. J. Soil Water Conserv. 40:450-454.
Williams, S.M., and R.R. Weil. 2004. Crop cover root channels may alleviate soil compaction effects on soybean crop. Soil Sci. Soc. Am. J. 68:1403-1409.

Wyland, L.J., L.E. Jackson, W.E. Chaney, K. Klonsky, S.T. Koike, and B. Kimple. 1996. Winter cover crops in a vegetable cropping system: Impacts on nitrate leaching, soil water, crop yield, pests and management costs. Agric. Ecosyst. Environ. 59:1-17.

Yoo, K.H., J.T. Touchton, and R.H. Walker. 1988. Runoff, sediment and nutrient losses from various tillage systems of cotton. Soil Tillage Res. 12:13-24.

Zhu, J.C., C.J. Gantzer, S.H. Anderson, E.E. Alberts, and P.R. Beuselinck. 1989. Runoff, soil, and dissolved nutrient losses from no-till soybean with winter cover crops. Soil Sci. Soc. Am. J. 53:1210-1214. 
